\title{
Bacterial Contamination and Over-Dilution of Commercial Infant Formula Prepared by HIV-Infected Mothers in a Prevention of Mother-to-Child Transmission (PMTCT) Programme, South Africa
}

\author{
by E. Andresen, ${ }^{\mathrm{a}}$ N. C. Rollins, ${ }^{\mathrm{b}}$ A. W. Sturm, ${ }^{\mathrm{c}}$ N. Conana, ${ }^{\mathrm{c}}$ and T. Greiner ${ }^{\mathrm{d}}$ \\ a Department of Women's and Children's Health, Uppsala University, Uppsala, Sweden, Departments of ${ }^{\mathrm{b}}$ Paediatrics and \\ Child Health, and ${ }^{\mathrm{c}}$ Medical Microbiology, The University of KwaZulu-Natal, Durban, South Africa, and ${ }^{\mathrm{d}} \mathrm{PATH} 1800 \mathrm{~K}$ St NW, \\ Suite 800, Washington DC 20006 USA
}

\section{Summary}

To examine the safety of formula feeds used by mothers participating in a Prevention of Motherto-Child Transmission (PMTCT) programme, contents of 94 feeding bottles collected at a PMTCTclinic were analysed. An additional 17 samples were taken from already prepared feeds during home visits, as well as 21 samples from bottles prepared under observation. Living conditions and educational levels were overall good and mothers had been counselled on safe formula preparation. Samples were analysed for faecal bacteria, using Escherichia coli and Enterococcus sp. as indicators. Protein concentration was used as an indicator of concentration of the formula. Out of 94, 63 (67\%) of samples obtained at the clinic and 13/16 (81\%) of available home samples were contaminated with faecal bacteria, compared to $8 / 21(38 \%)$ of those prepared under observation. Out of $94,58(62 \%)$ of the clinic samples containing $E$. coli and $23 / 94(24 \%)$ of those containing Enterococcus sp. were contaminated with more than the US government recommended limit of $10 \mathrm{CFU} / \mathrm{ml}$. Out of 94, 26 $(28 \%)$ of samples obtained at the clinic, 8/17 (47\%) of home samples and 3/21 (14\%) of those prepared under observation were over-diluted, compared to standards. Many mothers did not follow recommended practices in preparing and feeding the bottles.

\section{Introduction}

Inappropriate feeding practices are major contributing factors to high morbidity and mortality among infants and young children in developing countries [1]. Faecal bacteria in infant food are well known as a major cause of illness and associated

\section{Acknowledgements}

We thank SIDA/SAREC, NRF, HST and UNICEF for funding, University of the Western Cape, HST, the Medical Research Council and King Edward VIII Hospital, Durban, for general support to conduct the study. Dr Nceba Gqualenin at the Division of Human Biochemistry, the University of KwaZulu-Natal Durban, kindly supervised the protein analyses and Dr Juana Willumsen, Durban, kindly supervised the cleaning of the data.

Correspondence: Ted Greiner, Senior Nutritionist, PATH, $1800 \mathrm{~K}$ St NW, Suite 800, Washington DC, USA. Tel.: +1 202 822-0033; Fax: 202 457-1466.

E-mail<tgreiner@path-dc.org > (to be published). malnutrition in infants $[2,3]$. Several studies show high bacterial contamination of milk feeds prepared for infants, especially in feeding bottles $[2,4-8]$ and contamination is often associated with poor hygiene, unclean feeding utensils, low socio-economic status among mothers [9] and prolonged periods of storage $[2,8,10]$. ESPGHAN Committee on Nutrition, highlight that powdered infant formula is not sterile and may contain coliforms and other bacteria in low numbers; further that milk constitutes an excellent medium for bacterial growth and the importance of correct preparation, handling and storing of infant formula [11]. Over-dilution and/or over-concentration of infant milk feeds is another concern [12-18], putting the infant at risk of malnutrition [14], hypernatraemic dehydration [19, 20], hyperglycaemia, gangrene and coma [18]. Over-diluted feeds is often related to financial constraints [14, 21], while misunderstanding of manufacture's instructions, errors in scoop measurements with the use of heaped, packed or extra scoops of formula powder [12, 13, 22], or the assumption that 'the baby needs it' $[18,23]$, can result in serious over-concentration of feeds. 
An evaluation of the South African national Prevention of Mother-to-Child Transmission (PMTCT) pilot programme shows serious operational problems including provision of free infant formula, and also suggests inadequate counselling for the mothers in infant feeding decisions [24]. The aim of this cross-sectional study was to assess how HIVpositive mothers in an urban/peri-urban PMTCT area of KwaZulu Natal (KZN), South Africa, prepare and feed the infant milk to their infants and to assess the safety and adequacy of these feeds.

\section{Materials and Methods}

\section{Study population}

The study was done as a substudy within the Good Start Study, a prospective cohort study of mother-to-child HIV transmission in South Africa. The research took place in Durban at a PMTCTclinic at King Edward VIII Hospital. Free infant formula was provided for 6 months if mothers decided not to breastfeed, including counselling regarding safe preparation of artificial feeds.

All mothers attending the PMTCT-clinic exclusively or partially replacement feeding their infants, were invited to participate if they were carrying infant formula being used to feed their babies. Written and verbal information about the study were provided and signed free and informed consent forms were obtained. In total, 94 mothers participated. Research ethics committees at the University of Natal Durban and University of the Western Cape in South Africa and Uppsala University in Sweden approved the study design.

\section{Data collection and sampling}

Structured interviews were conducted, consisting of questions about general characteristics of the infant/ mother-pair, socio-economic and educational conditions and about preparation, handling, storing and hygienic practices of infant formula. After each interview, a sample was taken from any available feed as long as enough milk was left in the bottle to take an adequate sample. These were already prepared and ready for the child to drink; were being consumed by the child, or had been drunk from within the past half hour. Each questionnaire and formula sample was identified with an ID-number to ensure confidentiality.

A subsample of these mothers was asked for permission to visit them in their homes. They were not informed that samples were going to be collected, only that questions about formula milk would be asked. For 22 home visits, 17 samples were taken from milk that had been prepared before the arrival of the study team and 21 samples from feeds prepared while the visiting researcher observed. Due to difficulties in locating some mothers, the home visits were limited mainly to those living in the so-called formal settlements (houses/flats/room).

\section{Microbiological analyses}

Samples were analysed for proxy indicators of faecal bacterial contamination, namely Escherichia coli (E. coli) and Enterococcus sp. Standard volumes of milk were plated out on McConkey-I and Hoyles agar. Cultures for Salmonella sp. and for Shigella sp. were performed on xyloselysine-deoxycholate agar. All cultures were performed at the Department of Medical Microbiology, the University of KwaZulu-Natal, Durban. Samples obtained at the clinic were transported and stored at $4-5^{\circ} \mathrm{C}$ until inoculation on the same day. Cultures were incubated aerobically at $37^{\circ} \mathrm{C}$ overnight. Samples obtained in homes were inoculated onto their respective culture media on site, transported to the laboratory within 2-5 hours, and processed as described earlier. The US government limits the number of coliforms permitted in milk and dairy products to not more than 10 colony-forming units $/ \mathrm{ml}(\mathrm{CFU} / \mathrm{ml})$ [25], the cut-off used here in interpreting the level microbiological contamination of the feeds.

\section{Protein analyses}

Since mothers reported adding nothing else but formula and water to the bottles, protein concentration was used to measure the powder-water ratio of the formula. Protein concentration was measured in a LECO FP2000 Nitrogen Analyser using the Dumas Combustion Method at Agricultural Faculty Department of Animal and Poultry, University of Natal, Pietermaritzburg. Interpretation of chemical analysis was done according to Codex standards for infant formula by age [26, 27]. Since under and not over-concentration of feeds was the problem requiring attention in this sample, the following Codex cut-off points for the minimum protein content in infant formula were used to define samples that were over-diluted: not less than $1.8 \mathrm{~g} / 100$ available calories (kcal) for infants from 6-12 months and not less than $3.3 \mathrm{~g} / 100 \mathrm{kcal}$ for $1-3$ years of age.

\section{Data entry \& statistical analyses}

Data were entered and analysed using EPIINFO6 [28] and SPSS (Statistical Program for Social Science) [29]. Associations between contamination, concentration and procedures that could contribute to contamination and incorrect concentrations were explored by using odds ratios (OR). Fisher's exact test was also used, based on chi-squared tests for significance, when the number of mothers in any group was less than five. 


\section{Results}

General characteristics of study population and living conditions in households

The mean age of the infants was $5.7(0.3-16)$ months and the mean birth weight was $2.9(0.9-4.2) \mathrm{kg}$. The mean age of the mothers was $28(16-40)$ years. Out of $94,50(53 \%)$ of the mothers had $\geq 12$ years of formal education (Table 1). Out of 94, 68 (72\%) had electric refrigerators at home. Most of the families had access to piped drinking water, a flush toilet, electricity, a fridge, a radio and a TV (Table 2). Piped water in the area was known to be clean and safe for drinking, with no treatment needed for adults.

\section{Microbiological results}

Out of 94, $63(67 \%)$ of samples obtained at the clinic were contaminated with faecal bacteria $(60 \mathrm{E}$. coli, 24 Enterococcus sp. and 21 both), 13/16 (81\%) of home samples $(10$ E. coli, 9 Enterococcus sp. and 6 both) and $8 / 21(38 \%)$ of those prepared under observation ( 7 E. coli, 3 Enterococcus sp. and 2 both) (Table 3). Out of 94, 58 (62\%) of clinic samples containing E. coli and 23/94 (24\%) of those containing Enterococcus sp. were contaminated with more than $10 \mathrm{CFU} / \mathrm{ml}$ (Table 4). No salmonella or shigella were isolated.

\section{Protein results}

In total, 26/94 (28\%) of clinic samples (19/85 (22\%) for infants $0-12$ months of age and $7 / 9(78 \%)$ for the older children), 8/17 (47\%) of home samples and $3 / 21(14 \%)$ of those prepared under observation were over-diluted, as compared to Codex Alimentarius criteria (Table 5). Only one clinic sample, and none of the others, was over-concentrated.

\section{Infant feeding and hygienic practices}

As shown in Table 6, recommended safety time limit of 1 hour after making the feeds had elapsed for $83 / 94(88 \%)$ of clinic feeds and $12 / 17(71 \%)$ of home feeds. Out of 94, $9(10 \%)$ reported that it took a half a day or more for the child to finish a feed.

Though cup feeding was advised, all but three mothers used feeding bottles. Out of 94, 64 (68\%) said they always/often washed their hands before feed preparation, while 30/94 (32\%) sometimes/never did. All mothers reported boiling the water before preparing the milk, whether they did so directly before each feed or boiled and stored it for later use. Boiling water directly before preparing each feed significantly protected against $E$. coli contamination, $[(\mathrm{OR})=0.4$, confidence interval $(\mathrm{CI})=0.157-0.907]$. Possession of four or more bottles protected against E. coli contamination compared with owning fewer $(\mathrm{OR}=0.361, \mathrm{CI}=0.148-0.882)$.

Out of $94,57(61 \%)$ of the mothers kept left-over feeds to be used later for the child while 32/94 (34\%)
TABLE 1

General characteristics of the sample infants $(\mathrm{N}=94)$ and mothers $(\mathrm{N}=94)$

\begin{tabular}{|c|c|c|}
\hline & $N$ & $\%$ \\
\hline \multicolumn{3}{|l|}{ Gender of infants } \\
\hline Boys & 48 & 51 \\
\hline Girls & 45 & 48 \\
\hline Missing data & 1 & \\
\hline \multicolumn{3}{|l|}{ Age of infants in months } \\
\hline$<6$ & 59 & 63 \\
\hline $6-12$ & 26 & 28 \\
\hline$>12$ & 9 & 9 \\
\hline \multicolumn{3}{|l|}{ Birth weight of infants in gram } \\
\hline$<2500$ & 22 & 23 \\
\hline $2500-2999$ & 21 & 22 \\
\hline $3000-3499$ & 28 & 30 \\
\hline 3500-3999 & 21 & 22 \\
\hline$>4000$ & 1 & 1 \\
\hline Missing data & 1 & \\
\hline \multicolumn{3}{|l|}{ Maternal age in years } \\
\hline$<25$ & 24 & 26 \\
\hline $25-29$ & 38 & 40 \\
\hline $30-34$ & 20 & 21 \\
\hline$>34$ & 12 & 13 \\
\hline \multicolumn{3}{|l|}{ Mothers marital status } \\
\hline Married & 8 & 8 \\
\hline Partner & 59 & 63 \\
\hline Single & 26 & 28 \\
\hline Missing data & 1 & \\
\hline \multicolumn{3}{|c|}{$\begin{array}{l}\text { Mothers' level of education achieved/last } \\
\text { standard passed }\end{array}$} \\
\hline Diploma/college/ & 9 & 10 \\
\hline Completed high school $^{\mathrm{a}}$ & 41 & 44 \\
\hline $\begin{array}{l}\text { Started but not completed } \\
\text { high school }^{\text {b }}\end{array}$ & 36 & 38 \\
\hline $\begin{array}{l}\text { Higher primary } \\
\text { school or less }\end{array}$ & 6 & 6 \\
\hline No school & 1 & 1 \\
\hline Missing data & 1 & \\
\hline \multicolumn{3}{|l|}{ Mothers' main activity during the day } \\
\hline At home & 67 & 71 \\
\hline Unqualified job & 19 & 20 \\
\hline Qualified job ${ }^{\mathrm{d}}$ & 4 & 4 \\
\hline School & 1 & 1 \\
\hline $\begin{array}{l}\text { Mix of being at home } \\
\text { and at work }\end{array}$ & 2 & 2 \\
\hline Missing data & 1 & \\
\hline \multicolumn{3}{|c|}{ Main provider of income in the child's house } \\
\hline Mother herself & 21 & 22 \\
\hline Father of child/husband/partner & 20 & 21 \\
\hline Mother's own parent & 32 & 34 \\
\hline $\begin{array}{l}\text { Mother's grandparent/child } \\
\text { grant/relative or a mixed } \\
\text { income sources }\end{array}$ & 18 & 19 \\
\hline Missing data & 3 & \\
\hline
\end{tabular}

${ }^{\mathrm{a}} 12$ years of public school.

${ }^{\mathrm{b}} 8-11$ years of public school.

${ }^{c} 1-7$ years of public school (includes lower and higher primary school).

${ }^{\mathrm{d}}$ Higher education than high school needed. 
reported that they threw away unfinished feeds; five said the child always finished the feed. During the day, $43 / 94(46 \%)$ of the mothers prepared and gave the feed directly when the child wanted to feed, while the rest prepared extra for later use: 36/94 (38\%) stored covered at ambient temperature; $9 / 94(10 \%)$ in a fridge, 4/94 (4\%) in a bottle warmer and 2/94 (2\%) in a flask. At night, 35/94 (37\%) of the mothers fed milk directly after preparation, while the rest stored it for later use: $45 / 94(48 \%)$ at ambient temperature, $7 / 94(7 \%)$ in a bottle warmer, $4 / 94(4 \%)$ in a fridge and $2 / 94(2 \%)$ in a flask.

TABLE 2

Living conditions in the households $(\mathrm{N}=94)$

\begin{tabular}{|c|c|c|}
\hline & $N$ & $\%$ \\
\hline \multicolumn{3}{|c|}{ Water source for drinking } \\
\hline Piped-inside house & 62 & 66 \\
\hline Piped-in the yard & 16 & 17 \\
\hline Piped-public tap & 12 & 13 \\
\hline Borehole/well & 2 & 2 \\
\hline River & 2 & 2 \\
\hline \multicolumn{3}{|l|}{ Toilet } \\
\hline Flush toilet & 66 & 70 \\
\hline Latrine & 28 & 30 \\
\hline \multicolumn{3}{|l|}{ Fuel for cooking } \\
\hline Electricity & 70 & 75 \\
\hline Paraffin & 22 & 23 \\
\hline Wood/open fire & 2 & 2 \\
\hline \multicolumn{3}{|l|}{ Electric stove } \\
\hline Yes & 74 & 79 \\
\hline No & 20 & 21 \\
\hline \multicolumn{3}{|l|}{ Fridge } \\
\hline Yes & 68 & 72 \\
\hline No & 26 & 28 \\
\hline \multicolumn{3}{|l|}{ Radio } \\
\hline Yes & 81 & 86 \\
\hline No & 13 & 14 \\
\hline \multicolumn{3}{|l|}{ TV } \\
\hline Yes & 70 & 74 \\
\hline No & 24 & 26 \\
\hline \multicolumn{3}{|c|}{ Phone at home or cell phone } \\
\hline Yes & 52 & 55 \\
\hline No & 42 & 45 \\
\hline \multicolumn{3}{|l|}{ Car } \\
\hline Yes & 7 & 7 \\
\hline No & 87 & 93 \\
\hline
\end{tabular}

Most of the mothers cleaned the utensils before reuse, almost all had access to a bottlebrush, and a majority used detergent (Table 6). Out of 94 (76\%) reported using a sterilizing method but not always as the final step. Out of $94,12(13 \%)$ first sterilized the bottles and then washed and/or rinsed with water and soap. Some reported that they 'sterilized' by placing bottles into previously boiled water, and a few that they sterilized utensils once or twice a week.

Some mothers mentioned they did not clean the feeding utensil at night before reusing it and some only soaked, rinsed or shook the bottle in hot or cold water.

The use of a sterilizing method (boiling/sterilizing solution/bleach water) was associated with lower risk of E. coli contamination $(\mathrm{OR}=0.311 ; 95 \%$ $\mathrm{CI}=0.211,0.865)$, and sterilising solution alone with lower risk of Enterococcus sp. $(\mathrm{OR}=0.186$; $95 \% \mathrm{CI}=0.040,0.867)$. A cleaning cloth rather a bottlebrush increased the risk of Enterococci contamination ( $p=0.018$, Fisher's exact test).

As shown in Table 5, over-dilution was common but when asked to demonstrate how they made a feed, mothers generally prepared them correctly. Feeds made for infants under 6 months of age were less often over-diluted than feeds for older infants $[\mathrm{OR}=0.365(\mathrm{CI}=0.144-0.926)]$, even so for children less than 12 months of age compared with older children $[\mathrm{OR}=0.084(\mathrm{CI}=0.016-0.436)]$.

TABLE 4

Counts of E-coli and Enterococci in sampled milk feeds at clinic $(\mathrm{N}=94)$

\begin{tabular}{lrrrrr}
\hline \multirow{2}{*}{ No. of cfu $/ \mathrm{ml}$} & \multicolumn{2}{c}{ E-coli } & & \multicolumn{2}{c}{ Enterococci $\mathrm{sp.}$} \\
\cline { 2 - 3 } \cline { 5 - 6 } & $N$ & $\%$ & & $N$ & $\%$ \\
\hline 0 & 33 & 35 & & 64 & 68 \\
$1-10$ & 2 & 2 & & 1 & 1 \\
$11-100$ & 4 & 4 & & 3 & 3 \\
$101-1000$ & 13 & 14 & & 4 & 4 \\
$1001-10000$ & 12 & 13 & & 12 & 13 \\
$10001-100000$ & 19 & 20 & & 3 & 3 \\
$100001-200000$ & 4 & 4 & & \\
$>200000$ & 6 & 6 & & 1 \\
Missing & 1 & & 6 & \\
\hline
\end{tabular}

TABLE 3

Contamination of milk samples obtained at clinic and during home visits

\begin{tabular}{|c|c|c|c|c|c|c|c|}
\hline \multirow[t]{2}{*}{ Contamination } & \multicolumn{2}{|c|}{ E-coli } & \multicolumn{2}{|c|}{ Enterococci sp. } & \multirow{2}{*}{$\begin{array}{c}\text { Both } \\
N\end{array}$} & \multicolumn{2}{|c|}{ Either } \\
\hline & $N$ & $\overline{\%}$ & $N$ & $\%$ & & $N$ & $\%$ \\
\hline Clinic samples & $60 / 94$ & 64 & $24 / 94$ & 26 & 21 & $63 / 94$ & 67 \\
\hline Immediately available samples & $10 / 17$ & 59 & $9 / 16^{\mathrm{a}}$ & 56 & 6 & $13 / 16$ & 81 \\
\hline Samples prepared under observation in homes & $7 / 21$ & 33 & $3 / 21$ & 14 & 2 & $8 / 21$ & 38 \\
\hline
\end{tabular}

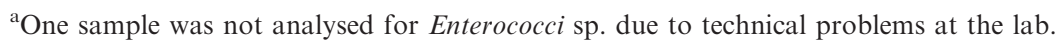


TABLE 5

Protein results from sampled milk feeds in comparison to Codex Alimentarius recommended levels

\begin{tabular}{|c|c|c|c|c|c|c|}
\hline & \multicolumn{2}{|c|}{ Clinic samples } & \multicolumn{2}{|c|}{ Home samples } & \multicolumn{2}{|c|}{ Observation samples } \\
\hline & $N=94$ & $\%$ & $N=17$ & $\%$ & $N=21$ & $\%$ \\
\hline Total milk samples within rec. levels & 67 & 71 & 9 & 53 & 18 & 86 \\
\hline Total milk samples outside rec. levels & 27 & 29 & 8 & 47 & 3 & 14 \\
\hline Level of protein for infants $0-12$ months: & $(N=85)$ & & $(N=16)$ & & $(N=20)$ & \\
\hline$<1.8 \mathrm{~g} / 100 \mathrm{kcal}$ & 19 & 22 & 7 & 44 & 2 & 10 \\
\hline $1.8-4.0 \mathrm{~g} / 100 \mathrm{kcal}$ (rec. levels) & 65 & 77 & 9 & 56 & 18 & 90 \\
\hline$>4.0 \mathrm{~g} / 100 \mathrm{kcal}$ & 1 & 1 & 0 & 0 & 0 & 0 \\
\hline Level of protein for infants $>12$ months: & $(N=9)$ & & $(N=1)$ & & $(N=1)$ & \\
\hline$<3.0 \mathrm{~g} / 100 \mathrm{kcal}$ & 7 & 78 & 1 & 100 & 1 & 100 \\
\hline $3.0-5.5 \mathrm{~g} / 100 \mathrm{kcal}$ (rec. levels) & 2 & 22 & 0 & 0 & 0 & 0 \\
\hline$>5.5 \mathrm{~g} / 100 \mathrm{kcal}$ & 0 & 0 & 0 & 0 & 0 & 0 \\
\hline
\end{tabular}

TABLE 6

Infant feeding and hygienic practices

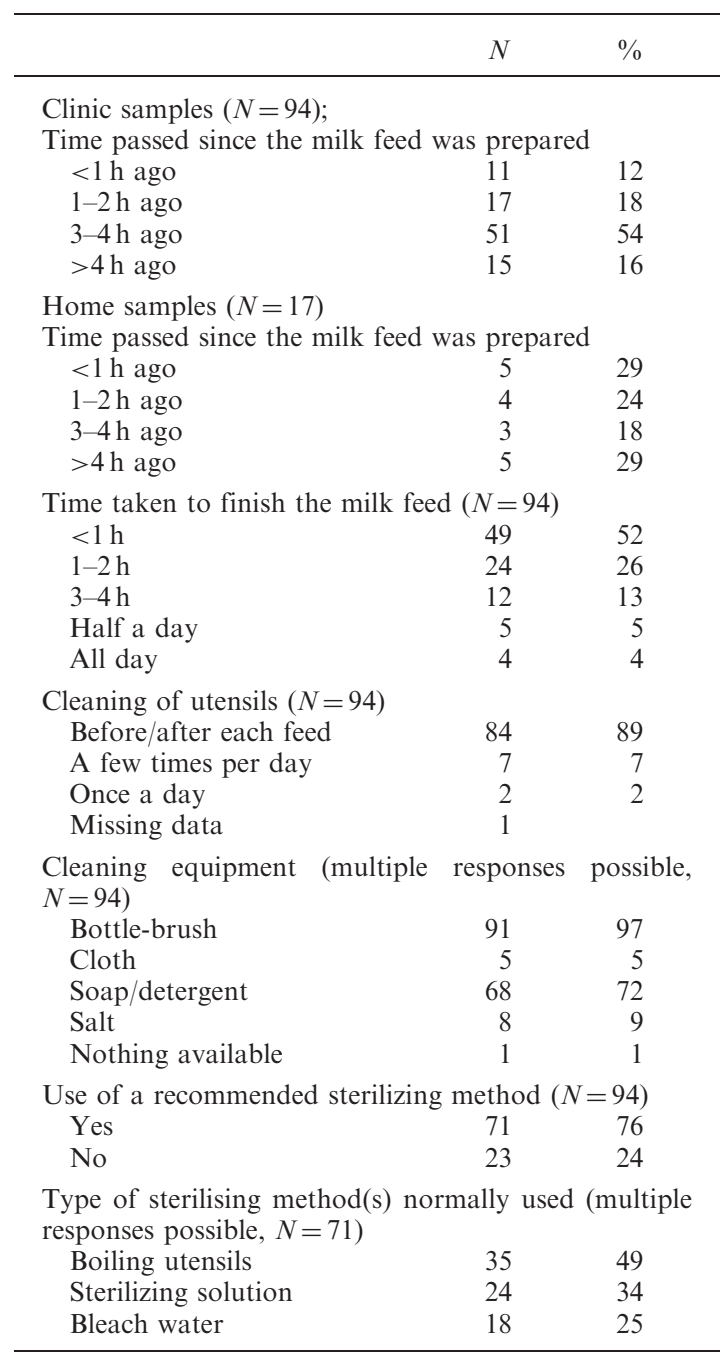

Mothers preparing smaller amounts of formula at one time $(75-150 \mathrm{ml})$ less often prepared over-diluted feeds than mothers preparing larger amounts $(175-1000 \mathrm{ml})[\mathrm{OR}=0.358(0.133-0.962)]$. Lack of access to running water indoors was associated with over-diluted feeds $[\mathrm{OR}=2.971(\mathrm{CI}=1.136-7.772)]$.

\section{Discussion}

Infant feeding involves many critical steps during handling-, storage-, preparation- and cleaning, putting great demands upon good measurement and hygiene if contaminated and unsafe feeds are to be avoided [11]. Results from this study confirm the difficulties mothers face in attempting to practice safe replacement feeding and the potential risks of health hazards for the infant even though counselling regarding safe preparation had been given.

We found heavy faecal contamination and overdilution of infant formula feeds among HIV-infected mothers participating in the national PMTCTprogramme in Durban, South Africa. In total, 62\% of the samples from the clinic containing E. coli and $24 \%$ of those containing Enterococcus sp. were contaminated with more than $10 \mathrm{CFU} / \mathrm{ml}$, above the accepted number of coliforms according to the US government standards [25]. A study in Bangkok, Thailand found coliform contamination above $100 \mathrm{CFU} / \mathrm{ml}$ in $66 \%$ of feeds [5]: $57 \%$ and $21 \%$ of the milk samples in the present study were contaminated with E. coli and Enterococcus sp., respectively at this level.

The women were typical of those enrolled in the PMTCT programme in both urban and periurban communities around Durban with demographic characteristics comparable to other reports from the region $(30,31)$. The home visit sample may however have been biased toward mothers who were better off and better able to safely artificially feed.

It is difficult for mothers to follow the complex set of recommended practices for safe bottle feeding, even in the USA [23]. The lower levels of 
contamination and over-dilution found in the feeds made under observation in this study suggest that mothers in the PMTCT-programme do not apply the knowledge they have of how to prepare feeds. Further and better quality counselling may help. Results here provide information that could be used to improve counselling of mothers choosing to artificially feed. However, some inappropriate practices may not improve. The fact that these mothers were relatively better off, both educationally and economically, than other mothers in other studies [8] suggests that risks in many other African PMTCT-settings may be more serious than those documented here.

\section{References}

1. WHO. Infant and young child nutrition, global strategy and young child nutrition. Report by the Secretariat, Fifty-fifth World Health Assembly 2002; A55/15.

2. Black RE, Brown KH, Becker S, et al. Contamination of weaning foods and transmission of enterotoxigenic Escherichia coli diarrhoea in children in rural Bangladesh. J Roy Soc Trop Med H 1982;76:259-64.

3. Motarjemi Y, Käferstein F, Moy G, et al. Contaminated weaning food: a major risk factor for diarrhoea and associated malnutrition. Bull WHO 1993;71:79-92.

4. Morais TB, Sigulem DM, Maranhão HS, et al. Bacterial contamination and nutrient content of home-prepared milk feeding bottles of infants attending a public outpatient clinic. J Trop Pediatrics 2005;51:87-92.

5. Suthienkul O, Siripanichgon K, Promachot P, et al. Bacterial contamination of bottle milk in infants under 6 months in Children's Hospital, Bangkok, Thailand. Southeast Asian J Trop Med Public Health 1999;30:770-5.

6. Morais TB, Morais MB, Sigulem DM. Bacterial contamination of the lacteal contents of feeding bottles in metropolitan São Paulo, Brazil. Bull WHO 1998;76:173-81.

7. Morais TB, Gomes TAT, Sigulem DM. Enteroaggregative Escherichia coli in infant feeding bottles. Lancet 1997;349:1448-9.

8. Imong SM, Jackson DA, Rungruengthanakit $\mathrm{K}$, et al. Maternal behaviour and socio-economic influences on the bacterial content of infant weaning foods in rural northern Thailand. J Trop Pediatr 1995;41:234-40.

9. Ray G, Nath G, Reddy DCS. Extents of contamination of top milk and their determinants in an urban slum of Varanasi, India. Indian J Public Health 2000;44:111-17.

10. Henry FJ, Patwary Y, Huttly SRA, et al. Bacterial contamination of weaning foods and drinking water in rural Bangladesh. Epidemiol Infect 1990;104:79-85.

11. Agostoni C, Axelsson I, Goulet O, et al. Preparation and handling of powdered infant formula: a commentary by the ESPGHAN Committee on Nutrition. J Pediatr Gastroenterol Nutr 2004;39:320-2.

12. Jeffs SG. Hazards of scoop measurements in infant feeding. J R Coll of Gen Pract 1989;39:113.

13. Lilburne AM, Oates RK, Thompson S, et al. Infant feeding in Sydney: a survey of mothers who bottle feed. Aust Paediatr J 1988;24:49-54.
14. McJunkin JE, Bithoney WG, McCormick MC. Errors in formula concentration in an outpatient population. J Pediatr 1987;111:848-50.

15. O'Donovan DJO, Riggall HM, Harland PSE. Dangerous infant feed preparation techniques: the role of maternal methods and improper formulae in Riyadh (Saudi Arabia). J Trop Pediatr 1985;31:94-6.

16. Hall DMB, Beal-Preston R, Geefhuysen $\mathrm{J}$, et al. Artificial feeding of black infants. S Afr Med J 1976;50:261-3.

17. Surjono D, Ismadi SD, Suwardji, Rohde JE. Bacterial contamination and dilution of milk in infant feeding bottles. J Trop Pediatr 1980;26:58-61.

18. Abrams CAL, Phillips LL, Berkowitz C, et al. Hazards of overconcentrated milk formula. JAMA 1975;232: 1136-40.

19. Abu-Ekteish F, Zahraa J. Hypernatraemic dehydration and acute gastro-enteritis in children. Ann Trop Paediatr 2002;22:245-9.

20. Chambers TL, Steel AE. Concentrated milk feeds and their relation to hypernatraemic dehydration in infants. Arch Dis Child 1975;50:610-15.

21. Hibbert JM, Seakins HAS, Jackson AA. Nutrient contents of bottle feeds of infants and children brought to clinics in Kingston, Jamaica. West Indian Med J 1980;29:134-41.

22. Oates RK. Infant feeding practices. $\mathrm{Br}$ Med $\mathrm{J}$ 1973;2:762-4.

23. Fein BS, Falci C. Infant formula preparation, handling and related practice in the United States. J Am Diet Assoc 1999;99:1234-40.

24. Doherty TM, McCoy D, Donohue S. Health system constraints to optimal coverage of the prevention of mother-to-child HIV transmission programme in South Africa: lessons from the implementation of the national pilot programme. Afr Health Sci 2005;5:213-18.

25. Jay JM. Indices of food quality; microbiological standards and criteria. In: Modern Food Microbiology, 3rd edn, New York: Van Nostrand Reinhold Co., 1986; pp. 409-28.

26. FAO/WHO: Codex Stan 72-1981. Codex standards for infant formula 1997. http://www.codexalimentarius. net/download/standards/288/CXS_072e.pdf (26 March 2007, date last accessed).

27. FAO/WHO: Codex Stan 72-1981. Codex standards for follow-up formula 1997. http://www.codexalimentarius. net/download/standards/293/CXS_156e.pdf (26 March 2007, date last accessed).

28. CDC/WHO: EPIINFO6; www.cdc.gov/epiinfo/, (12 October 2005, date last accessed).

29. SPSS; Statistical Program for Social Science, Version 11, 2002.

30. Doherty T, Chopra M, Nkonki L, et al. Effect of the HIV epidemic on infant feeding in South Africa: "When they see me coming with the tins they laugh at me". Bull World Health Organ. 2006;84(2):90-6.

31. Coovadia HM, Rollins NC, Bland RM, et al. Mother-to-child transmission of HIV-1 infection during exclusive breastfeeding in the first six months of life: an intervention cohort study. Lancet 2007;369(9567):1107-16. 